\title{
MICRO RAMAN SPECTROSCOPIC ANALYSIS ON BLOOD SERUM SAMPLES OF DUCTAL CARCINOMA PATIENTS
}

\author{
SANOJ VARGHESE ${ }^{1 *}$, AMBILI REVEENDRAN ${ }^{1}$, V.SENTHIL KUMAR ${ }^{1}$, KARTHIKEYAN TM$^{2}$, \\ VENKATESAN RANGANATHAN ${ }^{3}$
}

\begin{abstract}
${ }^{1}$ Department of Physics, Karpagam Academy of Higher Education, Coimbatore - 641 021, Tamil Nadu, India. ${ }^{2}$ Department of Pathology, Karpagam Faculty of Medical Sciences and Research, Coimbatore - 641 032, Tamil Nadu, India. ${ }^{3}$ Department of Oncology, Karpagam Faculty of Medical Sciences and Research, Coimbatore - 641 032, Tamil Nadu, India. Email: sanosown@gmail.com
\end{abstract}

Received: 20 May 2018, Revised and Accepted: 18 May 2018

\begin{abstract}
Objective: Identification of biochemical changes in ductal cancer patient's serum samples using micro Raman spectroscopy.

Methods: Micro Raman spectroscopy was used for the identification of Raman shift bands. Data analysis was done using K-means clustering.

Results: Micro Raman spectroscopic analysis of human breast cancer patient's serum samples was done. Biochemicals present in the samples were identified from the peak evaluations. K-means clustering analysis was used to differentiate the biochemicals present in the samples.
\end{abstract}

Conclusion: From the study, we conclude that Raman spectroscopy has the potential to differentiate the biochemical changes occurring in the human body, and the differentiation can be done using K-means clustering.

Keywords: Ductal cancer, Spectroscopy, Blood serum, Scattering.

(C) 2018 The Authors. Published by Innovare Academic Sciences Pvt Ltd. This is an open access article under the CC BY license (http://creativecommons. org/licenses/by/4. 0/) DOI: http://dx.doi.org/10.22159/ajpcr.2018.v11i9.26806

\section{INTRODUCTION}

Raman spectroscopy is an optical technique based on inelastic scattering of monochromatic light, interacting with a biological specimen. While light beam is embattled on sample molecules, a minute portion of the sprinkled light undergoes shifts in its frequency. These Raman shift amplitudes correspond to the vibrations of intermolecular bonds. Each molecule has an exclusive vibrational energy state that corresponds to an explicit Raman shift. As such, the Raman spectrum is a direct function of the molecular composition of the samples, and functional and structural changes may be evidenced by a change in Raman optical signature. The wealthy information contained in Raman spectra may be sufficient to recognize molecular changes in a sample compared to reflectance or fluorescence spectroscopy. Every molecule has its own vibrational pattern that can provide as Raman marker to provide the significant biochemical information hidden in the sample [1-4].

Frontline of defense for the treatment of cancers is surgery. Intraoperative assessment of tissue or demarcation of tumor margins has relied on conventional histopathological analysis of biopsied tissue or physical inspection based on pre-operative images. These conventional techniques are defective for the discovery of minute or premalignant lesion which results later in tardy analysis and supplementary surgery. Raman spectroscopy is supposed to have the perspective to pick up the diagnosis of a large number of malignancies, together with a lot of common and lethal cancers [5].

Raman spectroscopic technique might sense the variations of molecular arrangement and chemical composition. Throughout the development of a tumor, considerable changes will occur in the configuration and accumulation of the main biomolecules which make up the cell and tissue, such as, carbohydrates, lipids, proteins, and nucleic acids. Since biochemical variations happen in advance, then in the clinical indication of manifestation and tumor medical imaging discovery, molecular spectroscopy shows the prospective early analysis of a tumor. Sharp peak characteristics, which are free from the interference of water fewer samples are required for sample chemical treatment. Raman spectroscopy is a promising tool to comprehend real-time and non-invasive discovery at the molecular level [6-16]

In the present study, we are trying to identify the biochemical changes occurring in the breast cancer patient's blood serum samples which will lead to the detection of various malignancies in the early stage.

\section{METHODS}

Preparation of sample

Protocol approved by the Human Ethical Committee at Karpagam Faculty of Medical Sciences and Research, Coimbatore (IHE/77/ PHYSICS/03/2017), was followed for the procedures conducted. Serum samples from 15 ductal carcinoma patients before surgery and five normal persons were collected. All the serum samples were prepared by the same person with the same instruments.

\section{Blood sample collection}

Blood serum specimen was collected from 15 cases that were clinically diagnosed with cancer and five healthy volunteers. Serum was split from the blood by steadily stirring it with the use of a centrifuge at the speed of 1500 rotations/s. Samples were then stored at $-80^{\circ} \mathrm{C}$ to avoid exterior interface. The use of the samples for investigation did not have an effect on the course of the operation or treatment of the patient.

For Raman spectral measurements of the serum sample, a drop of $40 \mu \mathrm{L}$ was sited onto a silicon substrate positioned on the X-Y stage setting of a Witec microscope, attached to the Raman system. Raman spectrometer, bearing a laser wavelength of $785 \mathrm{~nm}$ having an irradiation power of $17 \mathrm{~mW}$, was used. The laser beam was fixed to the plane of the specimen with a $100 x$ point. Raman system was calibrated with a silicon semiconductor using Raman peak at 529/cm.

Processing of raw Raman spectra was done by carrying baseline modification, smoothing and normalization to eliminate noise, sample 
fluorescence, and short noise from cosmic rays to be finally analyzed using IBM SPSS software.

\section{RESULTS AND DISCUSSION}

\section{Baseline correction}

Origin 6 software was used for the baseline correction and identification of the peaks. The fast Fourier transform filter setup was used for smoothing. Number of points considered for smoothing were five. After this baseline, correction was done and the peak's values corresponding to the peaks were identified. The resulting graph is given below.

Normal serum samples show high intensity peaks at $753,844,949$, 1008, 1168, 1333, 1453, 1659, $1899 \mathrm{~cm}^{-1}$, etc. Each peak indicates the presence of particular biochemical variation occurring in the human body (Fig. 1). The main band assignments found are explained, as $753 \mathrm{~cm}^{-1}$ corresponds to the presence of tryptophan and 844/ $\mathrm{cm}$ represents the presence of tyrosine. At $949 \mathrm{~cm}^{-1}$ band for amide III is present and at $1008 \mathrm{~cm}^{-1}$ it shows symmetric C-C aromatic ring breathing, at $1168 \mathrm{~cm}^{-1} \mathrm{C}-\mathrm{C}$ stretch in amino acid, $1333 \mathrm{~cm}^{-1} \mathrm{CH}_{2}$ twist and bend, $\mathrm{CH}_{3}$ deformation (protein/lipid), nuclide acid, $1453 \mathrm{~cm}^{-1} \delta$ (CH2) bending, $\delta$ (CH3) out-of-phase, $1659 \mathrm{~cm}^{-1} \mathrm{C}=0$ stretch in amide I, and amino compound I alpha-helix.

In ductal carcinoma serum sample, main peak assignments are 856 , $908,949,1005,1171,1263,1330,1453,1659,1750,1864$, and $1899 \mathrm{~cm}^{-1} .856 \mathrm{~cm}^{-1}$ corresponds to side chain vibrations of amino acid in proline and hydroxyproline as well as c-c vibrations of collagen backbone and tyrosine, $1005 \mathrm{~cm}^{-1}$ corresponds to phenylalanine, 1171 corresponds to $\mathrm{C}-\mathrm{C}$ stretch amino acids, 1263 corresponds to $\mathrm{N}-\mathrm{H}$ bending in amide III, $1330 \mathrm{~cm}^{-1}$ corresponds to $\mathrm{CH} 2$ twist and bend, CH3 deformation (protein/lipid), nuclide acid, and $1750 \mathrm{~cm}^{-1} \mathrm{C}=0$ stretch (lipid). These are the main bands differentiated from normal serum samples (Table 1 and Fig. 2).

\section{K-means clustering of serum spectral data}

K-means clustering analysis was used to group the spectral data based on the similarity in forming clusters and region of similarity in biochemical properties. Biomolecular assignments considered for K-means clustering are protein, tryptophan, amide III, C-C stretch, NH amide III, and $\mathrm{CH}_{2}$ twist.
From Graph 1, the presence of $\mathrm{CH} 2$ twist is predominant and the occurrence of NH amide III is seen. Even though NH amide III is absent in cluster 2 , its presence in cluster 1 and 3 indicates the significance of $\mathrm{NH}$ amide III in the sample. f-values of protein (8.162), stretch (35.185), $\mathrm{NH}$ amide III (2.866), and CO stretch (12.328) show lower values in the normal samples than others in malignant samples. It indicates that among the four parameters all of them have a highly significant impact on the formation of clusters.

In malignant sample clustering, represented in cluster Graph 2, all the biochemical assignments show high f-values compared to normal that is protein (26.005), CC stretch (216.339), NH amide III (8.172), and CO stretch (11.438). This indicates all the parameters have less impact on the formation of the cluster. K-means clustering clearly differentiates between normal and malignant breast cancer samples.

From the literature survey, it is clear that the presence of proteins and amino acids is predominant in cancer patients when compared to that of the normal persons.

\section{CONCLUSION}

Analysis of blood serum samples of healthy persons and ductal breast cancer patients was done using micro Raman spectroscopy. Band assignments corresponding to the bands in the Raman spectra are identified. K-means clustering was used to find out the significance of biochemicals such as proteins, tryptophan, amide III, CC stretch, NH amide III, $\mathrm{CH} 2$ twist, and $\mathrm{CO}$ stretch of amino acids in the formation of clusters. From the study, it is clear that the malignant sample clearly differs from a normal sample. It is because all the biomolecules are in homogeneously distributed in the malignant sample.

\section{AUTHOR'S CONTRIBUTION}

All the authors have attributed directly to the planning, execution, or analysis of the work reported or to the writing of the paper.

\section{ACKNOWLEDGMENTS}

The authors would like to thank oncologists, operation theater staff, and nursing staff of Karpagam Faculty of Medical Science and research for expert advice and technical assistance.

Table 1: Assignment of serum Raman spectra for fingerprint region

\begin{tabular}{|c|c|c|}
\hline \multicolumn{3}{|c|}{ Wavenumber $\left(\mathrm{cm}^{-1}\right)$} \\
\hline Healthy person & Ductal carcinoma patients & Major assignments \\
\hline & 578 & Tryptophan \\
\hline \multirow[t]{2}{*}{753} & & Tryptophan, Thymine \\
\hline & 761 & Tryptophan \\
\hline \multirow[t]{2}{*}{844} & & Tyrosine lipid \\
\hline & 856 & $\begin{array}{l}\text { Amino acid side chain vibrations of proline and hydroxyproline } \\
\text { as well as c-c vibrations of collagen backbone, tyrosine }\end{array}$ \\
\hline \multirow[t]{3}{*}{949} & 949 & Amide III \\
\hline & 953 & Protein (C-C stretch protein backbone, alpha-helix), lipid \\
\hline & 1005 & Phenylalanine \\
\hline 1008 & 1008 & Symmetric $\mathrm{C}-\mathrm{C}$ aromatic ring breathing \\
\hline \multirow[t]{4}{*}{1168} & & C-C stretch amino acid \\
\hline & 1128 & Protein, lipid \\
\hline & 1171 & C-C stretch amino acids \\
\hline & 1263 & $\mathrm{~N}-\mathrm{H}$ bending in amide III \\
\hline 1333 & 1333 & $\begin{array}{l}\mathrm{CH}_{2} \text { twist and bend, } \mathrm{CH}_{3} \text { deformation (protein/lipid), nuclide } \\
\text { acid }\end{array}$ \\
\hline \multirow[t]{2}{*}{1453} & 1453 & $\delta\left(\mathrm{CH}_{2}\right)$ bending, $\delta\left(\mathrm{CH}_{3}\right)$ out-of-phase \\
\hline & 1564 & Guanine, adenine, tryptophan, and deformation mode of $\mathrm{C}=\mathrm{C}$ \\
\hline \multirow[t]{2}{*}{1659} & 1659 & $\mathrm{C}=0$ stretch in amide $\mathrm{I}$, amino compound $\mathrm{I}$, alpha-helix \\
\hline & 1750 & $\mathrm{C}=0$ stretch (lipid) \\
\hline
\end{tabular}




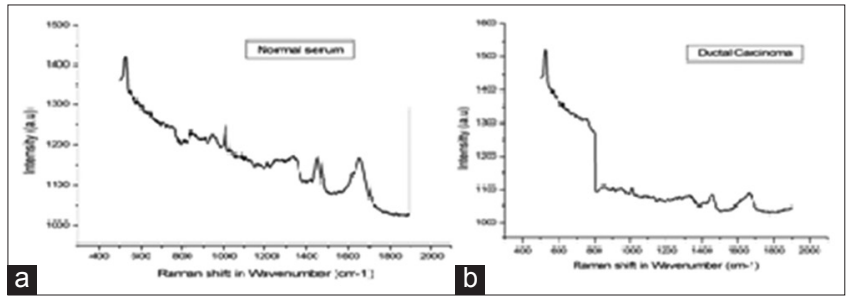

Fig. 1: ( $a$ and b) Unprocessed Raman plot of normal serum samples and ductal carcinoma serum samples, respectively

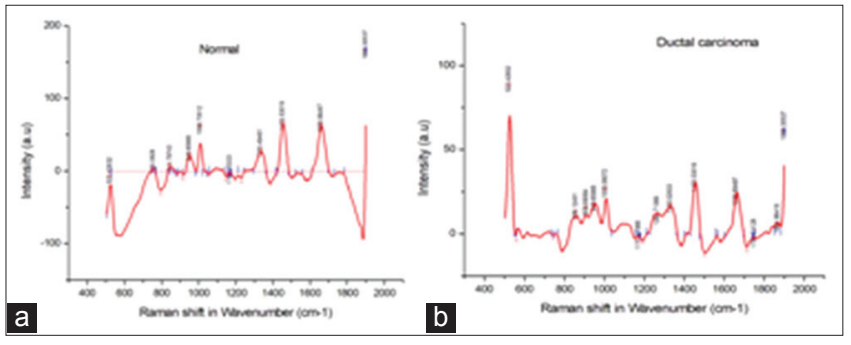

Fig. 2: (a and b) Raman shift to intensity plot of normal serum sample and ductal carcinoma serum sample, after baseline correction and smoothing

\section{CONFLICTS OF INTEREST}

We certify that regarding this paper, no actual or potential conflicts of interest exist. The paper is original, has not been accepted for publication nor is concurrently under consideration elsewhere, and will not be published elsewhere without the permission of the editor.

\section{FUNDING}

No financial support for research.

\section{REFERENCES}

1. Crow P, Uff JS, Farmer JA, Wright MP, Stone N. The use of Raman spectroscopy to identify and characterize transitional cell carcinoma in vitro. BJU Int 2004;93:1232-6.

2. Cauberg EC, de Bruin DM, Faber DJ, van Leeuwen TG, de la Rosette JJ, de Reijke TM, et al. A new generation of optical diagnostic for bladder cancer: Technology, diagnostic accuracy, and future applications. Eur Urol 2009;56:287-97.

3. Bensalah K, Tuncel A, Peshwani D, Zeltser I, Liu H, Cadeddu J, et al. Optical reflectance spectroscopy to differentiate a renal tumor from normal parenchyma. J Urol 2008:179:2010-3

4. Bensalah K, Pantuk AJ, Rioux-Leclercq N, Thuret R, Montorsi F, Karakiewicz PI, et al. Positive surgical margin appears to have a negligible impact on survival of renal cell carcinomas treaded by nephron-sparing surgery. Eur Urol 2010;57:466-73.

5. Jyothi BD, Sai SB, Lakshmi BC, Begum SK, Kumar AS. Awareness on cervical cancer-risk assessment. Int J Pharm Pharm Sci 2018;10:111-7.

6. Elgadir MA, Salama M, Adam A. Anti-breast cancer from various natural sources, review. Int J Pharm Pharm Sci 2015;7:181-3.

7. Fenn MB, Xanthopoulos P, Pyrgiotakis G, Grobmyer SR, Paedalos PM, Hench LL. Raman spectroscopy for clinical oncology. Adv Opt Technol 2011;2011:213783.

8. Li QB, Sun XJ, Xu YZ, Yang LM, Zhang YF, Weng SF, et al. Diagnosis of gastric inflammation and malignancy in endoscopic biopsies based on Fourier transform infrared spectroscopy. Clin Chem 2005;51:346-50.

9. Alfano RR, Tang GC, Pradan A, Lam W, Choy D, Opher E. Fluorescence spectra from cancerous and normal human breast and lung tissues. IEEE J Quantum Electron 1987;23:1806-11.

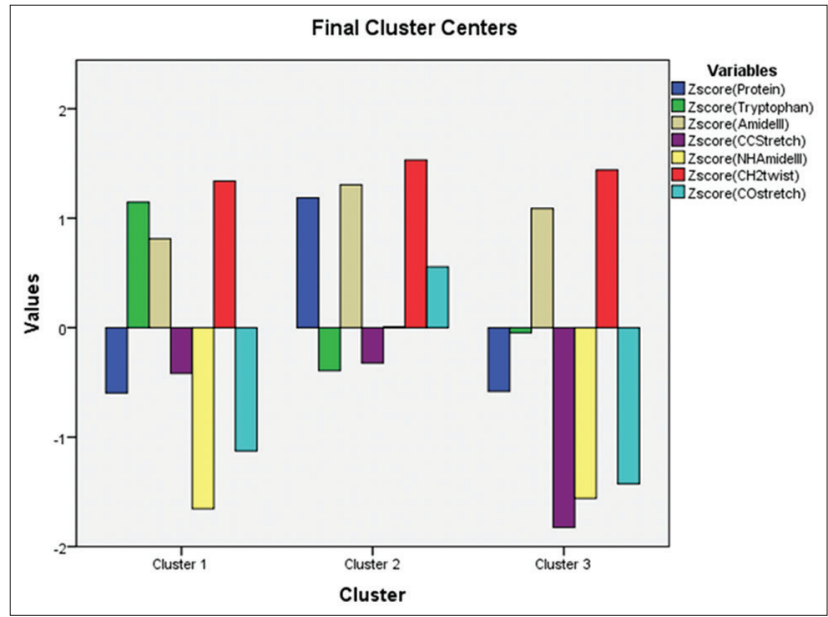

Graph 1: K-means clustering plot of normal serum sample

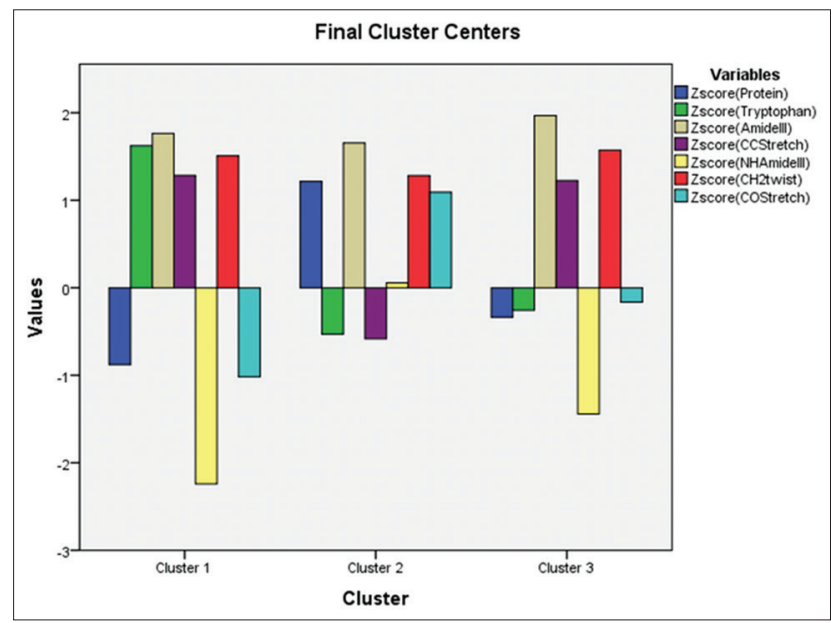

Graph 2: K-means clustering graph of ductal carcinoma patient serum sample

10. Rahman M, Islam SN. Effect of serum antioxidants (Vitamin E, C, and A) in lung cancer patients. Int J Pharm Pharm Sci 2014;6:126-8.

11. Alfano RR, Liu C, Sha WL, Zhu HR, Akins DL, Cleary J, et al. Human breast tissues studied by IR Fourier transform Raman spectroscopy. Lasers Life Sci 1991;4:23-8.

12. Pu Y, Wang WB, Yang YL, Alfano RR. Native fluorescence spectra of human cancerous and normal breast tissues analyzed with non-negative constraint methods. Appl Opt 2013;52:1293-301.

13. Teh SK, Zheng W, Ho KY, Teh M, Yeoh KG, Huang Z. Near-infrared Raman spectroscopy for early diagnosis and typing of adenocarcinoma in the stomach. Br J Surg 2010;97:550-7.

14. Haka AS, Volynskaya Z, Gardeki JA, Nazemi J, Lyons J, Hicks D, et al. In vivo margin assessment during partial mastectomy breast surgery using Raman spectroscopy. Cancer Res 2006;66:3317-22.

15. Haka AS, Volynskaya Z, Gardeki JA, Nazemi J, Shenk R, Wang N, et al. Diagnosing breast cancer using Raman spectroscopy: A prospective analysis. J Biomed Opt 2009; 14:054023.

16. Chowdary MV, Kumar KK, Mathew S, Rao L, Krishna CM, Kurien J. Biochemical correlation of Raman spectra of normal, benign and malignant breast tissue: A spectral deconvolution study. Biopolymers 2009;91:539-46. 